\title{
Iron Removal from Copper-based Alloy Scraps through Oxidation Slagging Process
}

\author{
Jia-yun WANG, ${ }^{1)}$ Hong-juan $\mathrm{LI}^{2}{ }^{2 *}{ }^{*}$ Lei $\mathrm{LI}^{,}{ }^{1)} \mathrm{Hua}_{\mathrm{WANG}},{ }^{1)} \mathrm{Yu} \mathrm{WANG}^{1)}$ and Yong YU ${ }^{1)}$ \\ 1) State Key Laboratory of Complex Non-ferrous Metal Resources Clean Utilization, Engineering Research Center of Metal- \\ lurgical Energy Conservation and Emission Reduction of Ministry of Education, Faculty of Metallurgical and Energy Engineer- \\ ing, Kunming University of Science and Technology, Kunming, 650093 China. \\ 2) Quality Development Institute, Kunming University of Science and Technology, Kunming, 650093 China.
}

(Received on December 26, 2017; accepted on April 11, 2018)

\begin{abstract}
A process of removing iron from copper-based alloy scraps using oxidation slagging method is researched, in which the iron is oxidized to $\mathrm{FeO}$ and then reacted with $\mathrm{SiO}_{2}$ forming $\mathrm{Fe}_{2} \mathrm{SiO}_{4}$ and enter into the slag phase. The addition of $\mathrm{SiO}_{2}$ could restrict the $\mathrm{Fe}_{3} \mathrm{O}_{4}$ generation through the transformation of $\mathrm{FeO}$ to $2 \mathrm{FeO} \cdot \mathrm{SiO}_{2}$ in a certain $\mathrm{O}_{2}$ pressure, which is favorable to decreasing the melt viscosity and increasing the separation efficiency of $\mathrm{Cu}$ and $\mathrm{Fe}$. Under optimized conditions of $\mathrm{O}_{2}$ flow rate of $40 \mathrm{ml} / \mathrm{min}$, temperature of $1673 \mathrm{~K}$, oxygenation time of $8 \mathrm{~min}$, and $\mathrm{SiO}_{2}$ amount of 2.17 mass \%, Fe content in the metal phase is decreased to 0.0030 mass $\%$ with $\mathrm{Cu}$ loss rate being of $1.14 \%$.
\end{abstract}

KEY WORDS: copper-based alloy scraps; iron remove; oxidation slagging; $\mathrm{SiO}_{2}$; waste utilization.

\section{Introduction}

With the shortage of primary copper resources, an increasing emphasis has been placed on the copper recovery from secondary sources, such as electroplating sludge, copper based alloy scraps, and anode slime, etc. ${ }^{1-4)}$ Specially, there is a gaining considerable interest to recover copper from copper based alloy scraps due to its large amount, economic point and increased requirement of environmental protection. $^{5,6)}$

Different $\mathrm{Cu}$ content in copper scraps corresponds to a different treatment process. The treatment of copper alloy scraps could be classified into two methods: pyrometallurgical and hydrometallurgical processes. ${ }^{5-24)}$ As for the purple copper scraps, the vertical furnace and reflector furnace are generally used to produce anode copper directly. For the copper scraps alloyed with other metals, a two-stage treatment process, containing smelting in blast furnace or blowing by the converter and then refining into the anode copper by reflector furnace, is generally used to recover copper from them. Most of copper alloy scraps have been recycled using pyrometallurgical process at present, but the recovery of $\mathrm{Re}, \mathrm{Ag}, \mathrm{Co}$ and other associated precious metal cannot be realized effectively. ${ }^{2,8-14)}$ In addition to the commonly used pyrometallurgical process, several hydrometallurgical methods have also been developed..$^{5-7,15-25)}$ Hydrometallurgical treatment of these materials, containing leaching, extraction and electrowining, is proposed as an alternative low-cost and environmental friendly technology. ${ }^{15,16)}$ However, it has

* Corresponding author: E-mail: 252972286@qq.com

DOI: http://dx.doi.org/10.2355/isijinternational.ISIJINT-2017-751 drawbacks such as complex process flows, high consumption of chemical reagents, and secondary environmental pollution. ${ }^{17)}$ Direct recovery of valuable metals from copper based alloy scraps is a comprising process with regard to the economy and environment, and several related processes have been developed for recovering metals using anodic dissolution. ${ }^{16,18,19)}$ In Chile, anode support system has been used in industrial electro-refining of copper scraps and blister copper granules, which claims an energy saving as high as $50 \%{ }^{20-24)}$ A simultaneous electroleaching-deposition process was also used to recover copper from printed circuit boards powder concentrates and achieved good experimental results. ${ }^{25)}$ However, when the $\mathrm{Fe}^{2+}$ concentration is $1-2$ $\mathrm{g} / \mathrm{L}, 6-9 \mathrm{~g} / \mathrm{L}$ and $10 \mathrm{~g} / \mathrm{L}$ in the electrolyte, the current efficiency is only $94 \%, 79 \%$ and $71 \%$ respectively, and further the high $\mathrm{Fe}^{2+}$ concentration increases the acid consumption obviously. ${ }^{25,26)}$ This Fe should be removed first before the hydrometallurgy treatment.

A method of fire refining-electrolysis complex process was proposed and this paper mainly investigated effects of processing parameters on the iron removal from a copper scrap using oxidative slagging method during the fire refining stage. The parameters including $\mathrm{O}_{2}$ flow rate, slagging temperature, oxygenation time and $\mathrm{SiO}_{2}$ addition amount were studied systematically.

\section{Experimental}

\subsection{Materials}

Table 1 gives chemical composition of the homogenized sample of copper-based alloy scraps (Fig. 1) by elemental analysis method and ICP-AES. It shows that the major ele- 
Table 1. Chemical composition of the copper-based alloy scrap (mass\%).

\begin{tabular}{cccccc}
\hline Element & $\mathrm{Cu}$ & $\mathrm{Fe}$ & $\mathrm{Ni}$ & $\mathrm{Zn}$ & Others \\
\hline Content & 96.97 & 3.01 & 0.002 & 0.0009 & 0.0171 \\
\hline
\end{tabular}

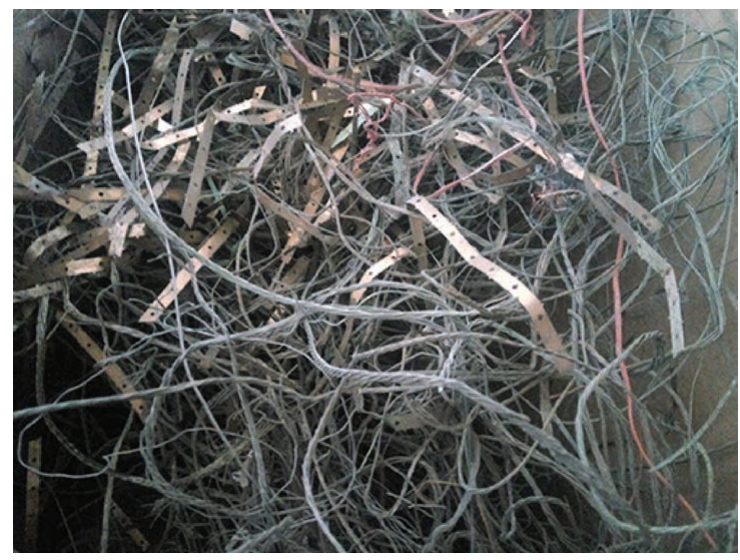

Fig. 1. The scrap appearance. (Online version in color.)

ments presented are copper (96.97 mass\%) and iron (3.01 mass \%). "Others" at a little content is mainly composed of "Si", "Ag", and "O" etc. Powdered $\mathrm{SiO}_{2}$ with $>99 \%$ purity used was purchased from Aladdin Industrial Corporation in Shanghai, China, and oxygen (purity of $99.9 \%$ ) was procured from local suppliers.

\subsection{Experimental Procedures}

The reaction system was set up in a tube furnace (TCW-32B, Shanghai Instrument Co. Ltd., China) as shown in Fig. 2, and the roasting temperature was measured by a $\mathrm{Pt}$-Rh thermocouple and controlled by a KSY Intelligent Temperature Controller (accuracy $\pm 1 \mathrm{~K}$ ). The $\mathrm{SiO}_{2}$ addition amount was calculated based on the quality ratio of $\mathrm{SiO}_{2}$ to the scrap in all the tests. The scrap was first crushed and sieved to yield a particle size below $741 \mu \mathrm{m}$ and mixed thoroughly with a given amount of $\mathrm{SiO}_{2}$. Then the mixture was placed in a corundum crucible, and then located in the corundum tube which was fastened in the vertical furnace under Ar atmosphere. The sample was raised from room temperature with a heating rate of $10 \mathrm{~K} / \mathrm{min}$ and then retained at a proper temperature for a stated time. When the scrap was melted completely, the $\mathrm{O}_{2}$ was injected into the melt through a corundum nozzle. The $\mathrm{O}_{2}$ flow rate was controlled by a flow meter. After a required time, the sample was cooled in Ar atmosphere, taken out when the temperature reached at room temperature, and prepared for analysis.

\subsection{Characterization}

Chemical composition and mineralogy of the samples were characterized by chemical analysis, ICP-AES, and EPMA. Especially, the "O" content in the sample was detected by XRF analysis (MINIPAL4, PANalytical, Netherlands). Phase compositions of all the samples were detected by XRD with $\mathrm{Cu} \mathrm{Ka}$ radiation (the scanning rate was per $8 \mathrm{deg}$ of 1 minute, and $2 \theta$ was 25 to $50 \mathrm{deg}$ ). The thermodynamic data of species were given by FactSage 7.0 thermochemical software. The mathematical expression of

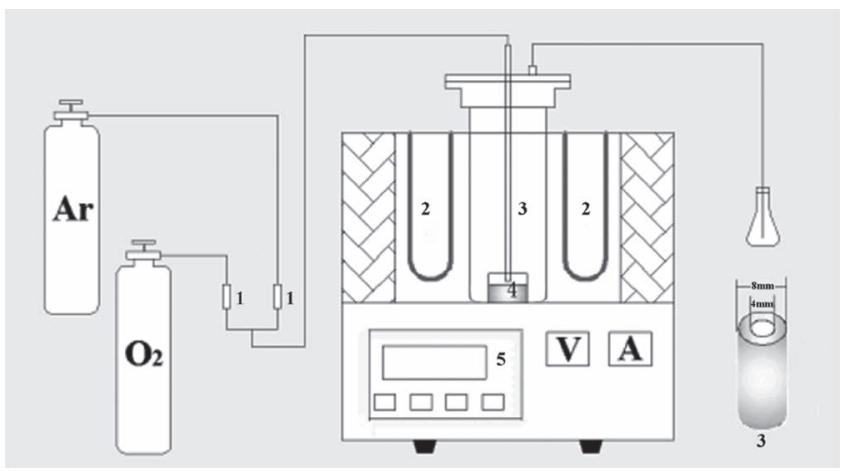

Fig. 2. Experimental apparatus. 1: Flowmeter, 2: Si-Mo heating component, 3: Corundum nozzle, 4: Corundum crucible, 5: Intelligent temperature controller.

$\mathrm{Cu}$ loss rate was defined as Eq. (1).

$$
R=\left(1-\frac{M_{D} \times W_{S 2}}{M_{O} \times W_{S 1}}\right) \times 100 \mathrm{pct}
$$

Where $R$ stands for the $\mathrm{Cu}$ loss rate, $M_{O}$ stands for mass of the scrap used, $W_{S 1}$ stands for copper content in the original scrap, $M_{D}$ stands for mass of the metal phase after treated, and $W_{S 2}$ stands for copper content in the metal phase after treated.

\section{Thermodynamic Analysis}

The FactSage 7.0 was used to calculate equilibrium phases in products in Gibbs free energy minimization under isothermal, isobaric and fixed mole conditions. Required data for computation were provided by FactPS database of the programme.

The calculations were performed for the mixture of 0.909 mole $\mathrm{Cu}$ and 0.032 mole Fe with variable amounts of $\mathrm{O}_{2}$ at temperature of $1573 \mathrm{~K}$. The phases of $\mathrm{FeO}, \mathrm{Fe}_{3} \mathrm{O}_{4}$, $\mathrm{Fe}_{2} \mathrm{O}_{3}, \mathrm{Cu}_{2} \mathrm{O}$ and $\mathrm{CuO}$ are assumed to be present in the products. Results of their equilibrium are present in Fig. 3. When $\mathrm{O}_{2}$ amount is less than 0.018 mole, Fig. 3 shows that the $\mathrm{Fe}$ is preferentially oxidized to $\mathrm{FeO}$ (Eq. (2)) and $\mathrm{Fe}_{2} \mathrm{O}_{3}$ (Eqs. (2)-(4)), ${ }^{27)}$ and the $\mathrm{Cu}$ stays in the form of metallic state. With $\mathrm{O}_{2}$ amount ranges from 0.018 to 0.022 mole, the $\mathrm{Cu}_{2} \mathrm{O}$ and $\mathrm{Fe}_{3} \mathrm{O}_{4}$ appear, and their amounts increase. Simultaneously, the $\mathrm{Fe}_{2} \mathrm{O}_{3}$ amount decreases, which implies that Eq. (5) happens in this stage. Increasing $\mathrm{O}_{2}$ amount further to 0.03 mole, the $\mathrm{FeO}, \mathrm{Fe}_{2} \mathrm{O}_{3}$ and $\mathrm{Cu}_{2} \mathrm{O}$ amounts increase while $\mathrm{Fe}_{3} \mathrm{O}_{4}$ decreases, indicating that the $\mathrm{Cu}$ can be directly oxidized to $\mathrm{Cu}_{2} \mathrm{O}$ through Eq. (6) except for Eqs. (5) and (6) plays a major role at a higher $\mathrm{O}_{2}$ pressure.

$$
\begin{array}{r}
2 \mathrm{Fe}+\mathrm{O}_{2}=2 \mathrm{FeO} \\
6 \mathrm{FeO}+\mathrm{O}_{2}=2 \mathrm{Fe}_{3} \mathrm{O}_{4} \\
4 \mathrm{Fe}_{3} \mathrm{O}_{4}+\mathrm{O}_{2}=6 \mathrm{Fe}_{2} \mathrm{O}_{3} \\
3 \mathrm{Fe}_{2} \mathrm{O}_{3}+2 \mathrm{Cu}=\mathrm{Cu}_{2} \mathrm{O}+2 \mathrm{Fe}_{3} \mathrm{O}_{4} \\
4 \mathrm{Cu}+\mathrm{O}_{2}=2 \mathrm{Cu}_{2} \mathrm{O} \ldots \ldots \ldots \ldots
\end{array}
$$

The $\mathrm{Fe}_{3} \mathrm{O}_{4}$ increases the melt viscosity, which goes against 
the separation of $\mathrm{Cu}$ and $\mathrm{Fe}$ oxides. In case of this, the $\mathrm{SiO}_{2}$ was added to decrease the $\mathrm{Fe}_{3} \mathrm{O}_{4}$ formation in a certain $\mathrm{O}_{2}$ pressure. FactPS and FToxid databases of the Factsage 7.0 were used to calculate the phase changes of $\mathrm{Fe}-\mathrm{O}$ thermodynamic system with the addition of $\mathrm{SiO}_{2}$ at 1 atm pressure of shielding gas, and the results are shown in Figs. 4 and 5. Compared them, it can be seen that some part of thermodynamically stable region of $\mathrm{Fe}_{3} \mathrm{O}_{4}$ (gray area in Fig. 4) has transformed to $\mathrm{Fe}_{2} \mathrm{SiO}_{4}$ (red region in Fig. 5) with the

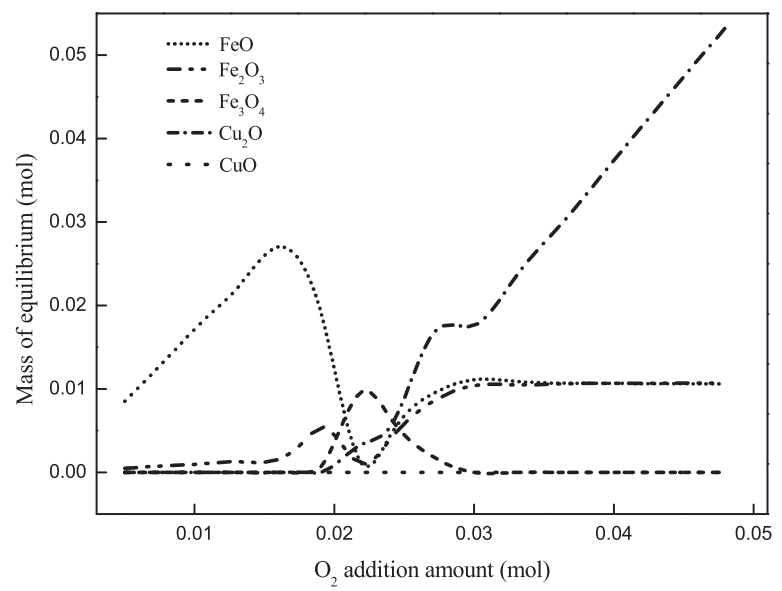

Fig. 3. Equilibrium phase changes in products with $\mathrm{O}_{2}$ amount at $1573 \mathrm{~K}$.

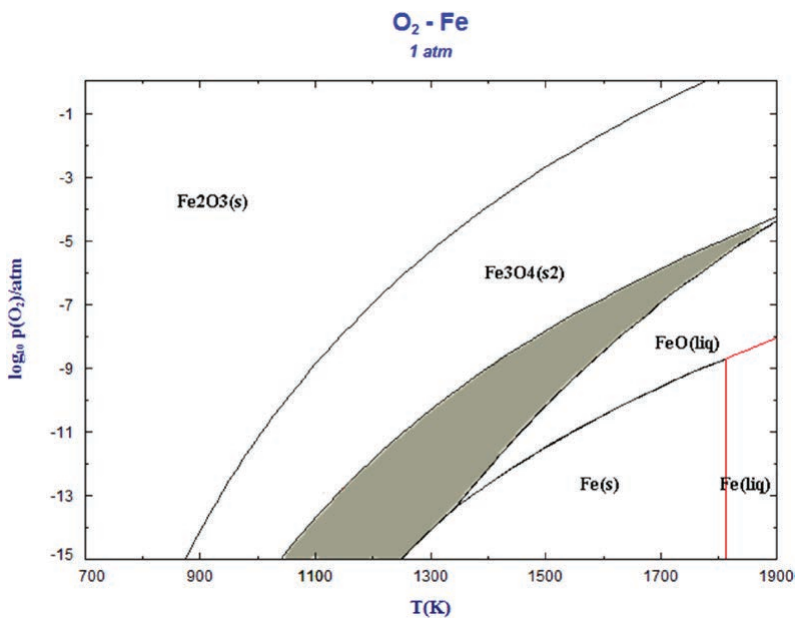

Fig. 4. Phase diagram of $\mathrm{Fe}-\mathrm{O}_{2}$. (Online version in color.)

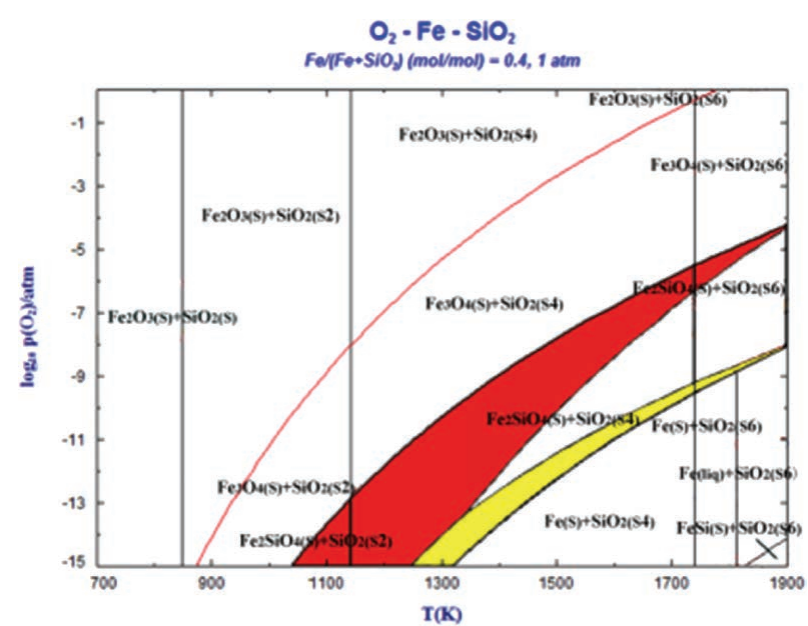

Fig. 5. Phase diagram of $\mathrm{Fe}-\mathrm{O}_{2}-\mathrm{SiO}_{2}$. (Online version in color.) addition of $\mathrm{SiO}_{2}$. In Fig. 5, the red and yellow areas are both thermodynamically stable regions of $\mathrm{Fe}_{2} \mathrm{SiO}_{4}$. Specifically, the red area shows that after the $\mathrm{SiO}_{2}$ addition, part of thermodynamically stable region of $\mathrm{Fe}_{3} \mathrm{O}_{4}$ has transformed to $\mathrm{Fe}_{2} \mathrm{SiO}_{4}$ and $\mathrm{SiO}_{2}$ stable region, and the yellow area means part of $\mathrm{Fe}$ stable region has transformed to that of $\mathrm{Fe}_{2} \mathrm{SiO}_{4}$ and $\mathrm{SiO}_{2}$.

\section{Results and Discussion}

\subsection{Effects of $\mathrm{O}_{2}$ Flow Rate}

Under slagging temperature of $1523 \mathrm{~K}$, oxygenation time of $10 \mathrm{~min}$, and $\mathrm{SiO}_{2}$ amount of 2.17 mass $\%$, five $\mathrm{O}_{2}$ flow rates of $25,40,55,70$, and $85 \mathrm{ml} / \mathrm{min}$ were chosen for studying the effects on iron remove and copper loss from the scrap.

Figure 6 shows that the $\mathrm{Fe}$ content in the metal phase (Fig. 7) after treatment decreases from 1.30 to 0.0039 mass $\%$ with $\mathrm{O}_{2}$ flow rate from 25 to $85 \mathrm{ml} / \mathrm{min}$, while the copper loss rate increases from 1.32 to $5.72 \%$. Figure 8 shows that the main $\mathrm{Fe}$ phase is $2 \mathrm{FeO} \cdot \mathrm{SiO}_{2}$ in the slag phase with $\mathrm{O}_{2}$ flow rate of $40 \mathrm{ml} / \mathrm{min}$, and the $\mathrm{Cu}$ exits in the form of $\mathrm{Cu}_{2} \mathrm{O}$ and $\mathrm{CuFe}_{2} \mathrm{O}_{4}$. Increasing $\mathrm{O}_{2}$ flow rate to $55 \mathrm{ml} / \mathrm{min}$,

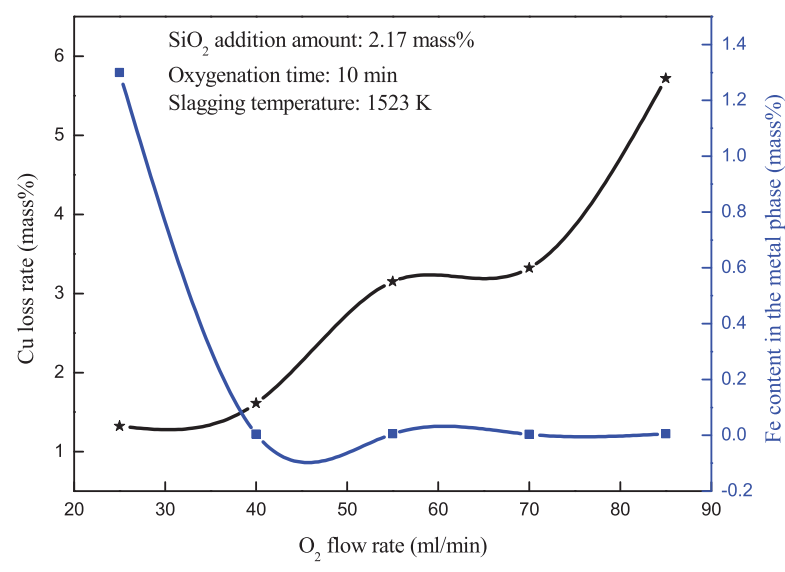

Fig. 6. Effects of $\mathrm{O}_{2}$ flow rate on the iron remove and copper loss from scraps. (Online version in color.)

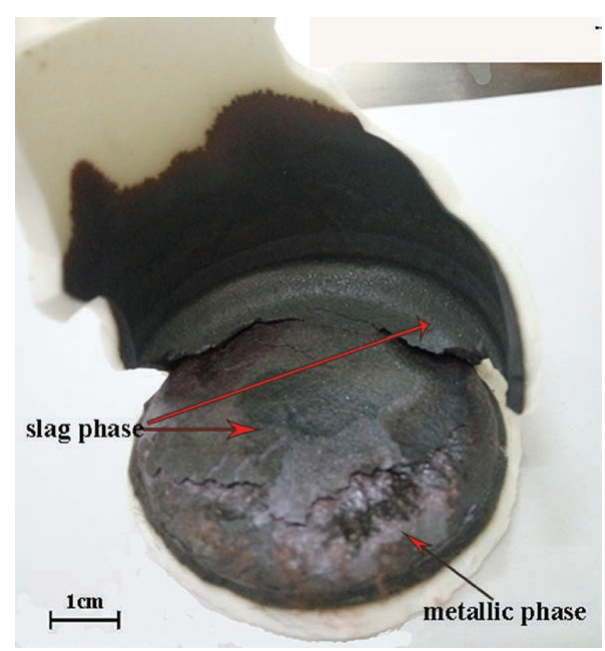

Fig. 7. Sample appearance after scrap treatment under slagging temperature of $1523 \mathrm{~K}$, oxygenation time of $10 \mathrm{~min}, \mathrm{SiO}_{2}$ amount of $2.17 \mathrm{mass} \%$, and $\mathrm{O}_{2}$ flow rate of $25 \mathrm{ml} / \mathrm{min}$. (Online version in color.) 


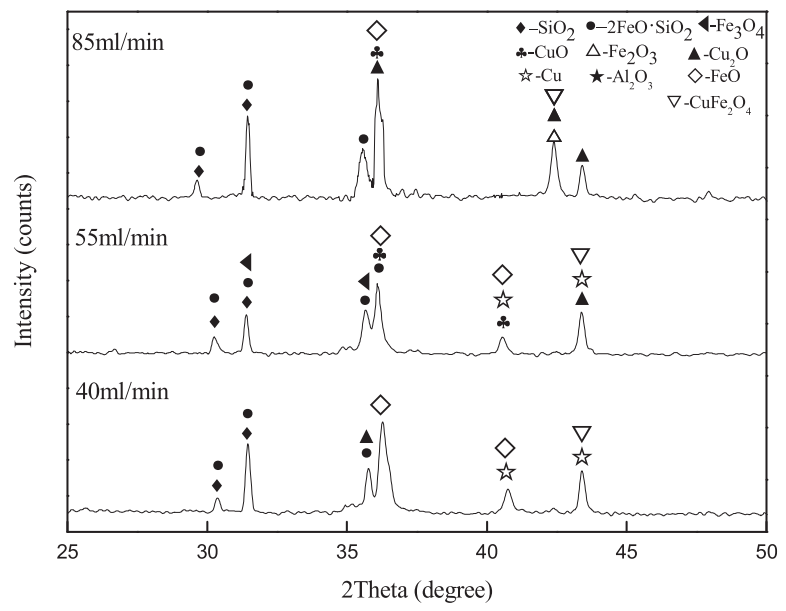

Fig. 8. XRD patterns of the slag at $\mathrm{O}_{2}$ flow rate of $40 \mathrm{ml} / \mathrm{min}$, $55 \mathrm{ml} / \mathrm{min}$ and $80 \mathrm{ml} / \mathrm{min}$.

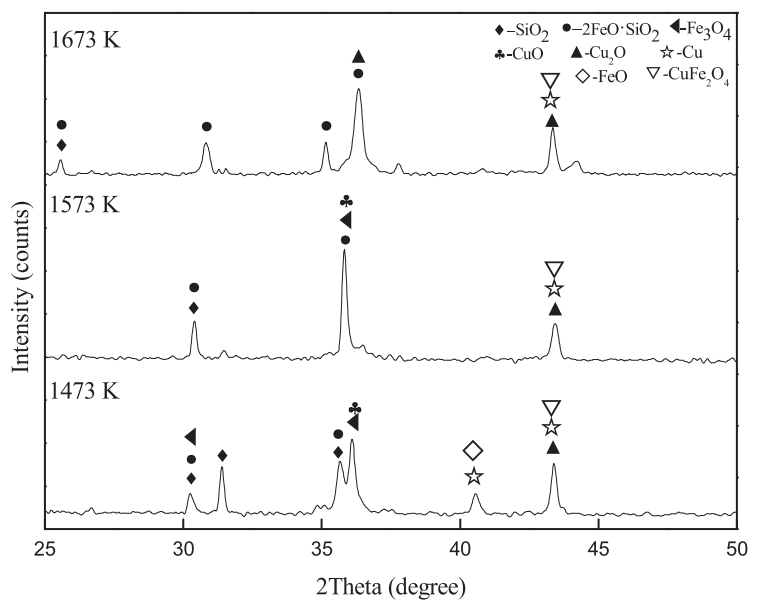

Fig. 10. XRD patterns of the slag at slagging temperature of $1473 \mathrm{~K}, 1573 \mathrm{~K}$ and $1673 \mathrm{~K}$.
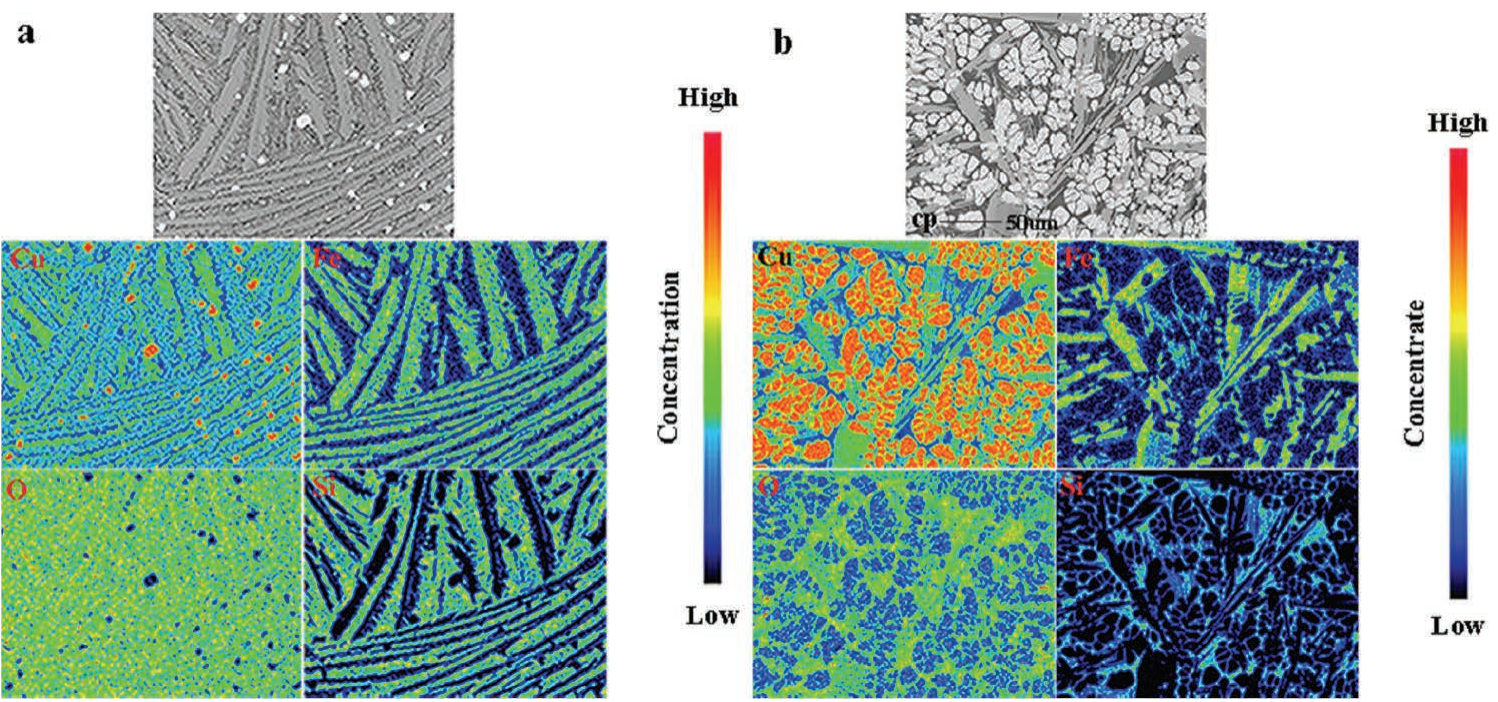

Fig. 9. EPMA analysis of the slag at different $\mathrm{O}_{2}$ flow rates (a, $55 \mathrm{ml} / \mathrm{min} ; \mathrm{b}, 85 \mathrm{ml} / \mathrm{min}$ ). (Online version in color.)

massive $\mathrm{Fe}_{3} \mathrm{O}_{4}$ (Fig. 8) are generated through Eq. (5), which causes an increase of the molten slag viscosity during the slagging stage. As a result, the $\mathrm{Cu}$ entrainment loss in the form of $\mathrm{Cu}$ phase seen from Fig. 8 increases and the copper loss rate increases in Fig. 6. The $\mathrm{Fe}_{3} \mathrm{O}_{4}$ amount decreases accompanied with the appearance of $\mathrm{Fe}_{2} \mathrm{O}_{3}$ with the $\mathrm{O}_{2}$ flow rate from 55 to $85 \mathrm{ml} / \mathrm{min}$, which accords well with that in Fig. 1. It implies that some $\mathrm{Cu}$ has been oxidized directly by $\mathrm{O}_{2}$ and lost in the slag deduced from Fig. 1. Compared Figs. 9(a) with 9(b), the $\mathrm{Cu}_{2} \mathrm{O}$ amount increases at $\mathrm{O}_{2}$ flow rate of $85 \mathrm{ml} / \mathrm{min}$, and it causes $\mathrm{Cu}$ loss rate increase as shown in Fig. 6. For the purpose of increasing iron remove and reducing copper loss, the $\mathrm{O}_{2}$ flow rate is determined as $40 \mathrm{ml} / \mathrm{min}$.

\subsection{Effects of Slagging Temperature}

With $\mathrm{O}_{2}$ flow rate of $40 \mathrm{ml} / \mathrm{min}$ and $\mathrm{SiO}_{2}$ amount of 2.17 mass $\%$, effects of slagging temperature on the iron remove were tested. The increase of slagging temperature decreases the melt viscosity. Besides, the $\mathrm{Fe}_{3} \mathrm{O}_{4}$ formation could be restricted at a higher temperature through the transformation of $\mathrm{FeO}$ to $\mathrm{Fe}_{2} \mathrm{SiO}_{4}$ deduced from Fig. 5, also resulting in a decrease of the melt viscosity. Figure 10 shows that increasing slagging temperature from 1473 to $1673 \mathrm{~K}$, the $\mathrm{Fe}_{2} \mathrm{SiO}_{4}$ intensity increases obviously accompanied with the decrease of $\mathrm{Fe}_{3} \mathrm{O}_{4}$ intensity. As a result, the $\mathrm{Cu}$ entrainment loss decreases with temperature (Fig. 11) and the copper loss rate decreases from 3.02 to $1.31 \%$ (Fig. 12). In addition, the iron content in the metal phase after treatment is decreased from 0.0043 to 0.0033 mass $\%$ due to a higher oxidation and slagging rate at a higher temperature. Increasing temperature to $1703 \mathrm{~K}$, more $\mathrm{Cu}$ is oxidized to copper oxides and lost in the slag, causing the copper loss rate and iron content in the metal phase after treatment both increase as shown in Fig. 12. For increasing the separation efficiency of $\mathrm{Cu}$ and $\mathrm{Fe}$, the appropriate slagging temperature is $1673 \mathrm{~K}$.

\subsection{Effects of Oxygenation Time}

Under the conditions of $\mathrm{O}_{2}$ flow rate of $40 \mathrm{ml} / \mathrm{min}, \mathrm{SiO}_{2}$ addition amount of 2.17 mass $\%$ and slagging temperature of $1673 \mathrm{~K}$, the equilibrium phase changes in products with oxygenation time is calculated using FactSage 7.0, and the result is shown in Fig. 13. Figure 13 shows that increasing oxygenation time to $8 \mathrm{~min}$, the $\mathrm{Fe}$ amount decreases accompanied with $\mathrm{Fe}_{2} \mathrm{SiO}_{4}$ amount increasing, and then $\mathrm{Fe}_{3} \mathrm{O}_{4}$ and $\mathrm{Fe}_{2} \mathrm{O}_{3}$ phases appear with oxygenation time over $8 \mathrm{~min}$ and $11 \mathrm{~min}$ respectively. Meanwhile, the $\mathrm{CuFe}_{2} \mathrm{O}_{4}$ 

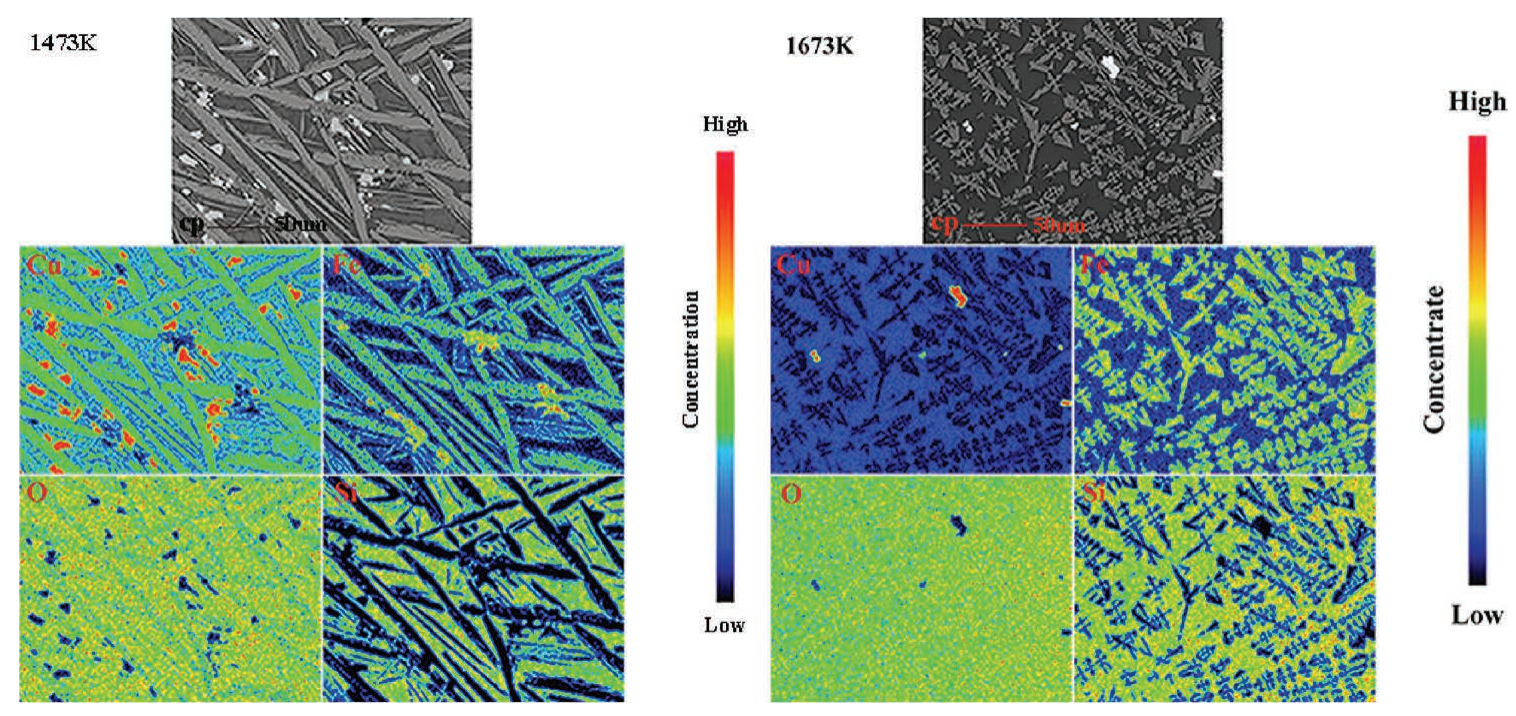

Fig. 11. EPMA analysis of the slag at slagging temperature of $1473 \mathrm{~K}$ and $1673 \mathrm{~K}$. (Online version in color.)

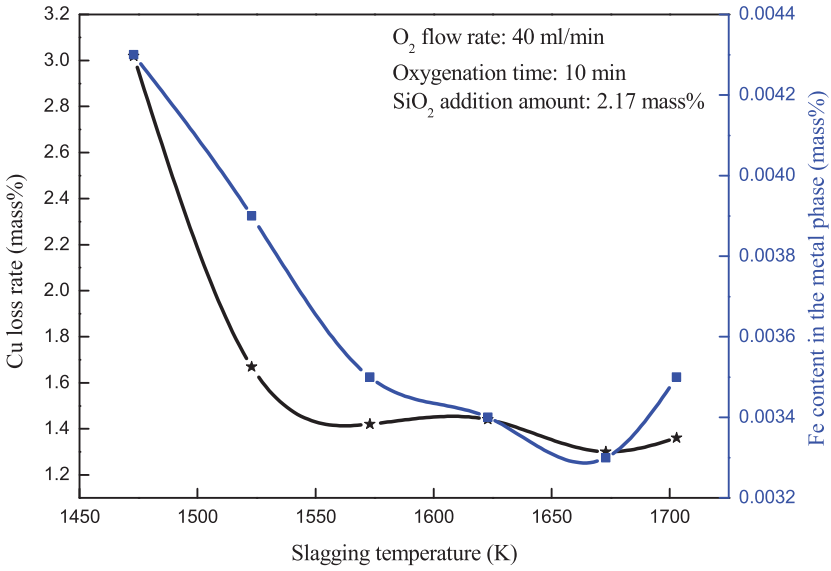

Fig. 12. Effects of slagging temperature on the iron remove and copper loss from scraps. (Online version in color.)

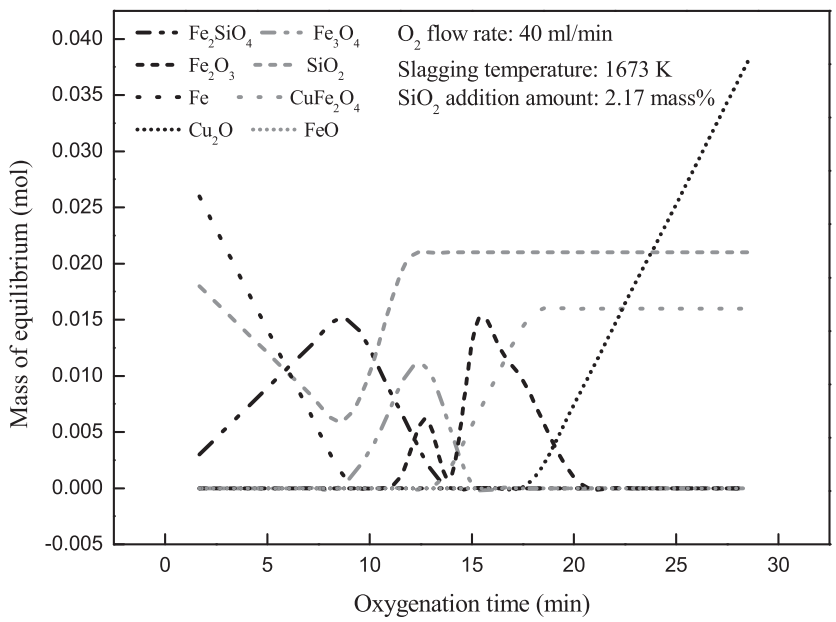

Fig. 13. Equilibrium phase changes in products with oxygenation time at $1673 \mathrm{~K}$.

formed between $\mathrm{CuO}$ and $\mathrm{Fe}_{2} \mathrm{O}_{3}$ appears at oxygenation time of $12.9 \mathrm{~min}$ and $\mathrm{Cu}_{2} \mathrm{O}$ appears at oxygenation time of $17.3 \mathrm{~min}$, and both of them increase with oxygenation time. The appropriate oxygenation time is $8 \mathrm{~min}$ from the view of thermodynamic.

The experimental results in Fig. 14 shows that the $\mathrm{Fe}$

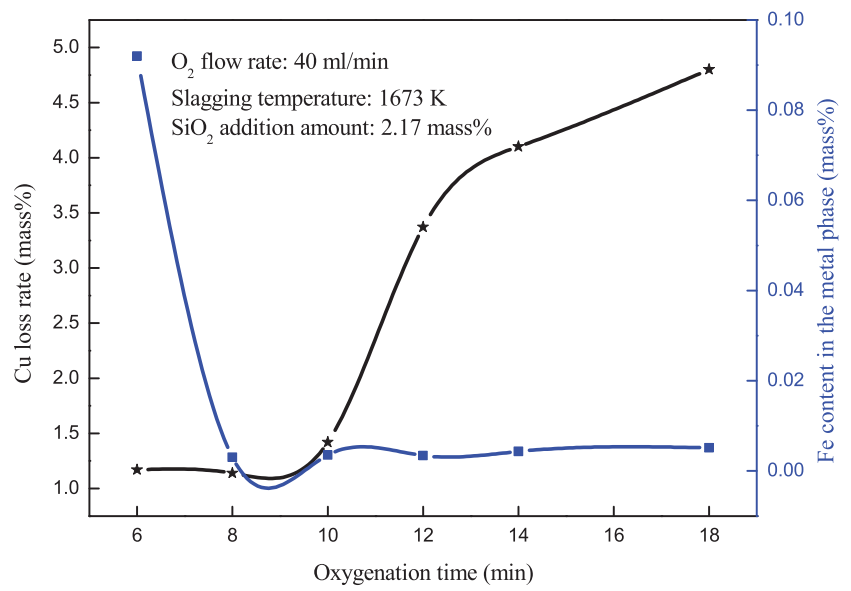

Fig. 14. Effects of oxygenation time on the iron remove and copper loss from scraps. (Online version in color.)

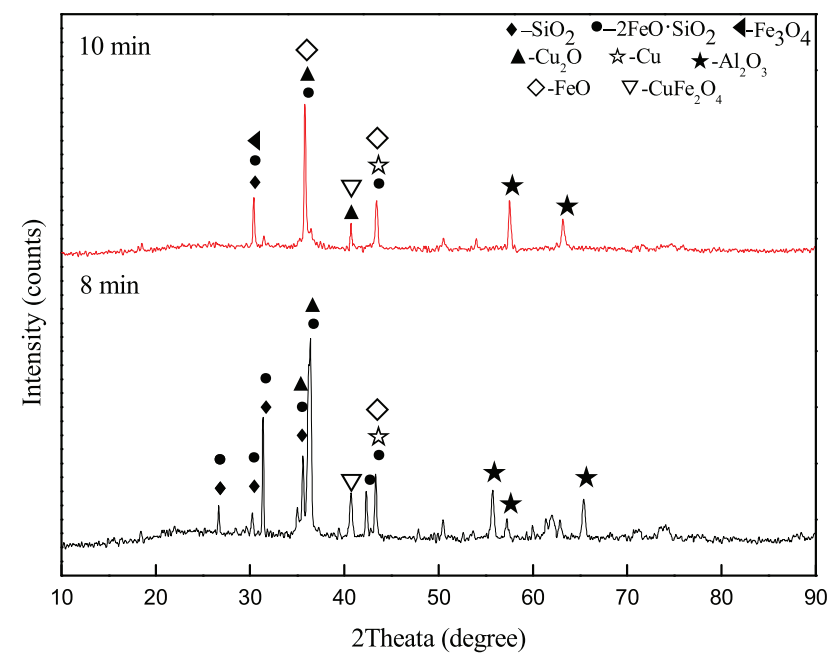

Fig. 15. XRD patterns of the slag at the oxygenation time of $8 \mathrm{~min}$ and $10 \mathrm{~min}$. (Online version in color.)

content in the metal phase after treatment decreases from 0.092 mass $\%$ to 0.003 mass $\%$ with oxygenation time from 6 to $8 \mathrm{~min}$, and the $\mathrm{Cu}$ loss rate is low to $1.14 \%$ and changes little in this time range. Increasing oxygenation time over 8 min, the $\mathrm{Fe}_{3} \mathrm{O}_{4}$ appears (Fig. 15) causing the melting 
slag viscosity increase, as a result of which the copper loss rate increases in Fig. 14. For the purpose of increasing the Fe removal rate and decreasing the copper loss, the oxygenation time is determined as $8 \mathrm{~min}$, which accords well with the result of thermodynamics equilibrium calculation in Fig. 13.

\subsection{Effects of $\mathrm{SiO}_{2}$ Addition Amount}

In a certain range, the addition of $\mathrm{SiO}_{2}$ promotes the $\mathrm{Fe}$ to be oxidized to $\mathrm{FeO}$ through the formation of $2 \mathrm{FeO} \cdot \mathrm{SiO}_{2}$ and restricts the generation of $\mathrm{Fe}_{3} \mathrm{O}_{4}$ deduced from Figs. 4, 5 and 13. That increases the iron remove from the scrap. Figure 16 shows that with the increase of $\mathrm{SiO}_{2}$ amount from 1.5 to 2.17 mass $\%$, the Fe content in the metal phase after treatment decreases from 0.0063 to 0.003 mass $\%$ accompanied with a slight decrease of $\mathrm{Cu}$ loss rate. When the $\mathrm{SiO}_{2}$ amount exceeds 2.17 mass\%, the number of $\mathrm{SiO}_{2}$ solid particle in the melt during the slagging process increases (Fig. 17), as a result of which the melt viscosity increases and it hinders the Fe oxidation through decreasing the $\mathrm{O}_{2}$ mass transfer rate. As a result, the $\mathrm{Cu}$ loss rate and
Fe content in the metal phase after treatment both increase as shown in Fig. 16. The appropriate $\mathrm{SiO}_{2}$ addition amount is 2.17 mass $\%$.

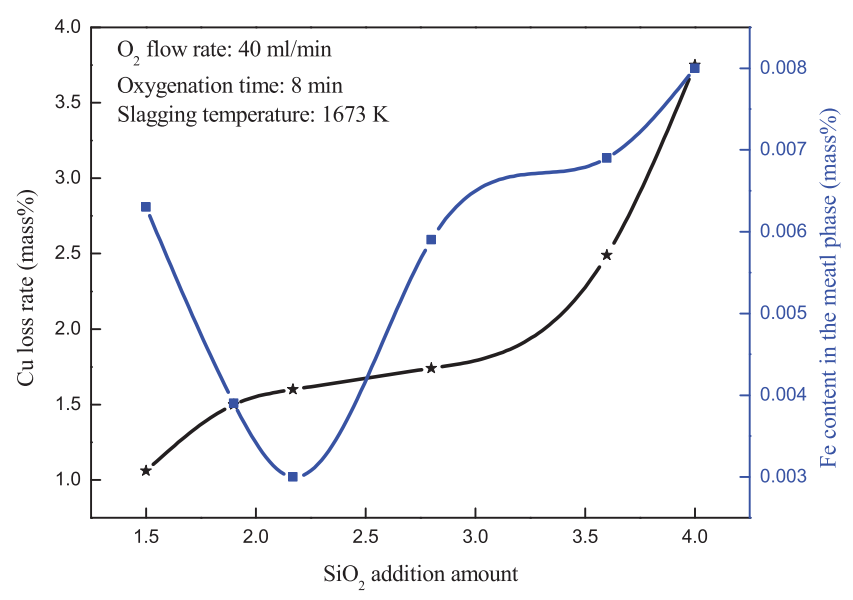

Fig. 16. Effects of $\mathrm{SiO}_{2}$ addition amount on the iron remove and copper loss from scraps. (Online version in color.)
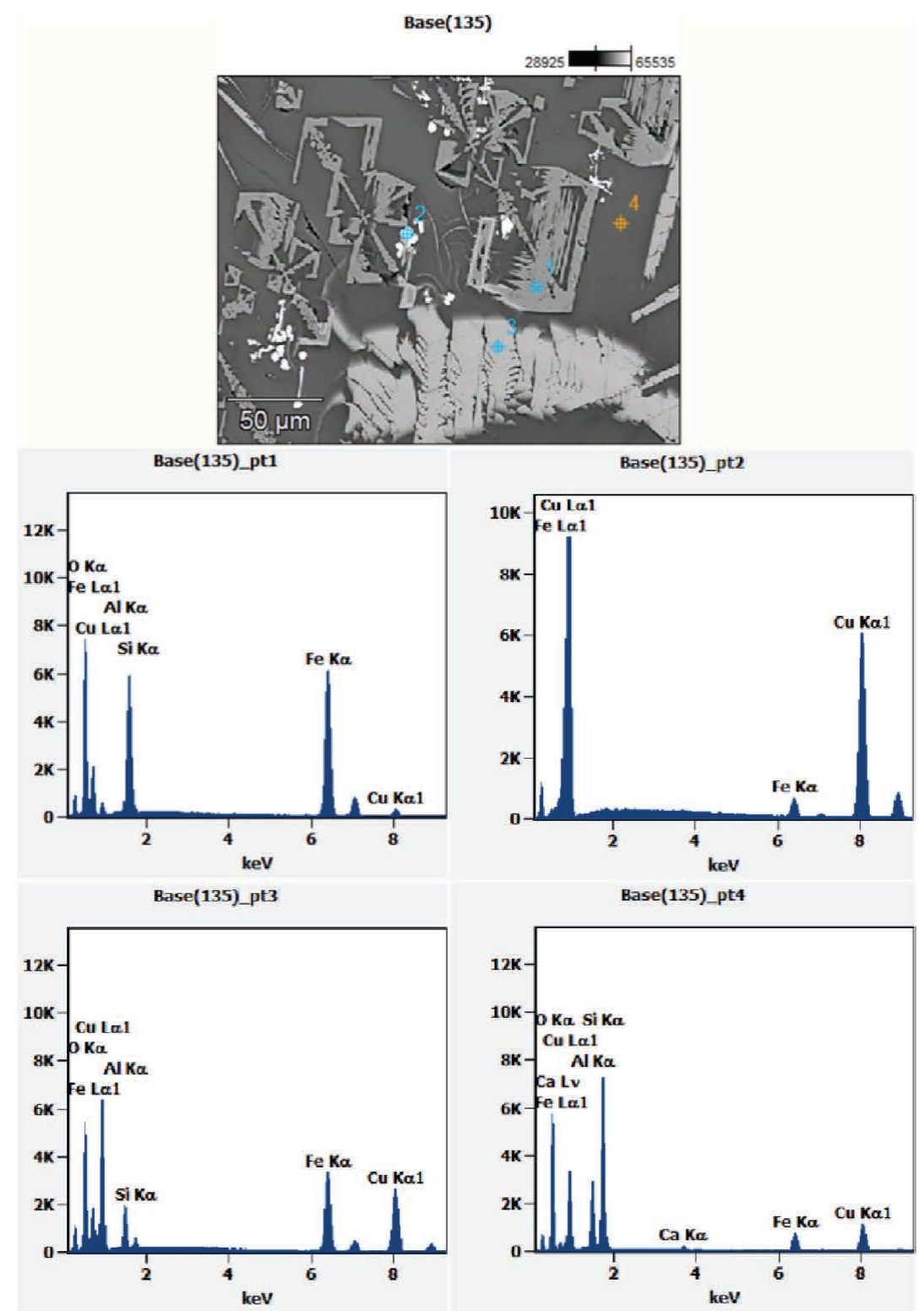

Fig. 17. Mineral phase distribution of the slag with $\mathrm{SiO}_{2}$ addition amount of 3.6 mass\%. (Online version in color.) 
Based on the discussion above, it can be concluded that removing iron from the copper based alloy scraps through oxidation slagging process is viable. Under conditions of $\mathrm{O}_{2}$ flow rate of $40 \mathrm{ml} / \mathrm{min}$, slagging temperature of $1673 \mathrm{~K}$, oxygenation time of $8 \mathrm{~min}$ and $\mathrm{SiO}_{2}$ addition amount of 2.17 mass $\%$, the Fe content in the metal phase is decreased to 0.003 mass $\%$ accompanied with a $\mathrm{Cu}$ loss rate low to $1.14 \%$. The iron content in the metal phase fulfills the requirement of iron content in the anode copper. ${ }^{28,29)}$

\section{Conclusions}

The effective remove of iron from copper-based alloy scraps through oxidation slagging process is practicable. The factors, including $\mathrm{O}_{2}$ flow rate, slagging temperature, oxygenation time, and $\mathrm{SiO}_{2}$ addition amount, play important roles in the process of iron remove.

At a low $\mathrm{O}_{2}$ amount, the $\mathrm{Cu}$ is oxidized to $\mathrm{Cu}_{2} \mathrm{O}$ mainly by $\mathrm{Fe}_{2} \mathrm{O}_{3}$, and it can also be directly oxidized by $\mathrm{O}_{2}$ at a higher $\mathrm{O}_{2}$ amount and plays a major role compared to the oxidation of $\mathrm{Fe}_{2} \mathrm{O}_{3}$ from the point of view of thermodynamics. As a result, the $\mathrm{Cu}$ loss rate increases with $\mathrm{O}_{2}$ flow rate and oxygenation time. The addition of $\mathrm{SiO}_{2}$ restricts the $\mathrm{Fe}_{3} \mathrm{O}_{4}$ generation through the transformation of $\mathrm{FeO}$ to $2 \mathrm{FeO} \cdot \mathrm{SiO}_{2}$ in a certain $\mathrm{O}_{2}$ pressure, which is favorable to decreasing the melt viscosity and increasing the separation efficiency of $\mathrm{Cu}$ and $\mathrm{Fe}$. Under optimized conditions of $\mathrm{O}_{2}$ flow rate of $40 \mathrm{ml} / \mathrm{min}$, temperature of $1673 \mathrm{~K}$, slagging oxygenation time of $8 \mathrm{~min}$, and $\mathrm{SiO}_{2}$ amount of 2.17 mass $\%$, $\mathrm{Fe}$ content in the metal phase is decreased to 0.0030 mass $\%$ with $\mathrm{Cu}$ loss rate being of $1.14 \%$.

\section{Acknowledgments}

The authors wish to express thanks to National Science Fund for General Projects (51574135) for financial supports of this research.

\section{REFFERENCES}

1) G. R. F. A. Flores, S. Nikolic and P. J. Mackey: JOM, 66 (2014),
823

2) A. Agrawal and K. K. Sahu: Resour. Conserv. Recycl., 54 (2010), 401.

3) A. Y. Zhu, J. L. Chen, L. I. Zhou, L. Y. Luo, Q. Lei and L. Zhang: Trans. Nonferr. Met. Soc. China, 23 (2013), 1349.

4) Y. Ma and K. Qiu: Vacuum, 106 (2014), 5.

5) F. Wang, H. J. Li, L. Li, X. F. Xie, S. W. Qiu and J. Q. Yu: Chin. J. Process Eng., 16 (2016), 266 (in Chinese).

6) B. Sengupta, M. S. Bhakhar and R. Sengupta: Hydrometallurgy, 99 (2009), 25.

7) S. Nigo, H. Majima, T. Hirato, Y. Awakura and M. Iwai: J. MMIJ, 109 (1993), 337.

8) Y. L. Xu, S. M. Xu, G. Xu and R. A. Chi: Chin. J. Nonferr. Met., 19 (2009), 760 (in Chinese).

9) A. Anindya, P. D. Swinbourne, P. M. Reuter and R. Matusewicz: Proc. European Metallurgical Conf. (EMC), Vol. 2, European Metal Conference, Aachen, (2009), 555.

10) Z. Liu, W. Chen and Q. Shen: Miner. Process. Extr. Metall., 112 (2003), 137.

11) D. F. Qiu, C. Y. Wang and C. Wang: Nonferr. Met., 55 (2003), 94 (in Chinese)

12) M. A. T. Cocquerel and M. G. Burcher: Conserv. Recycl., 2 (1978), 111.

13) S. K. Sahu: Metallurgy, (2008), 71.

14) A. Jokilaakso, T. Ahokainen, O. Teppo, Y. X. Yang and K. Lilius: Miner. Process. Extr. Metall. Rev., 15 (1995), 217.

15) A. Khaliq, M. A. Rhamdhani, G. Brooks and S. Masood: Resources, 3 (2014), 152.

16) E. Rudnik, K. Kołczyk and D. Kutyła: Trans. Nonferr. Met. Soc. China, 25 (2015), 2763

17) D. Pant, D. Joshi, M. K. Upreti and R. K. Kotnala: Waste Manag., 32 (2012), 979.

18) M. Aghazadeh, A. Zakeri and M. S. Bafghi: Hydrometallurgy, 111-112 (2012), 103.

19) C. Lupi and D. Pilone: Proc. Extraction and Processing Division (EPD) Cong., 1998, Tms Meeting, San Antonio, (1998), 427.

20) M. Figueroa, R. Gana, L. Kattanl and A. Parodi: J. Appl. Electrochem., 24 (1994), 206

21) M. Figueroa, R. Gana, L. Kattan, S. Me'Ndez and L. Palma: J. Appl. Electrochem., 27 (1997), 99.

22) R. Gana, M. Figueroa, L. Kattan and S. Castro: J. Appl. Electrochem., 23 (1993), 813.

23) R. Gana, M. Figueroa, L. Kattan, J. M. Sánchez and M. A. Esteso: J. Appl. Electrochem., 25 (1995), 240.

24) R. Gana, M. Figueroa, L. Kattan, I. Moller and M. A. Esteso: J. Appl. Electrochem., 25 (1995), 1052.

25) Y. F. Guimaraes, I. D. Santos and A. J. B. Dutra: Hydrometallurgy, 149 (2014), 63.

26) Z. C. Jin: Min. Metall., 28 (2012), 27 (in Chinese).

27) R. Y. Chen and W. Y. D. Yeun: Oxid. Met., 59 (2003), 433.

$28)$ A. Owais, M. A. H. Gepreel and E. Ahmed: Hydrometallurgy, 152 (2014), 55

29) M. O. Ilkhchi, H. Yoozbashizadeh and M. Sadegh Safarzadeh: Chem. Eng. Process., 46 (2007), 757. 